\title{
IN VITRO CYTOTOXICITY AND ANTIOXIDANT EVALUATION OF BIOGENIC SYNTHESIZED GOLD NANOPARTICLES FROM MARSILEA QUADRIFOLIA ON LUNG AND OVARIAN CANCER CELLS
}

\author{
BALASHANMUGAM P.1*, MOSACHRISTAS K. ${ }^{2,3}$, KOWSALYA E. ${ }^{2,3}$
}

${ }^{1}$ Centre for Human and Organisational Resources Development (CHORD), CSIR-Central Leather Research Institute, Chennai, 600020, Tamil Nadu, India, ${ }^{2}$ Loyola College, Sterling Road, Nungambakkam, Chennai 600034, Tamil Nadu, India, ${ }^{3}$ Avanz Bio Pvt. Ltd., M. E. S Road, East Tambaram, Chennai 600059, Tamil Nadu, India

*Email: biobala17@gmail.com

Received: 18 Jun 2018, Revised and Accepted: 19 Jul 2018

\section{ABSTRACT}

Objective: The biogenic gold nanoparticles are considered to be extremely impressive for its wide range of applications in pharmaceutics and therapeutics. The present study was aimed at the biogenic synthesis of gold nanoparticles (AuNPs) from Marsilea quadrifolia aqueous extract and to investigate its antioxidant property and cytotoxic effect on human ovarian teratocarcinoma (PA-1) and lung adenocarcinoma (A549) cell lines.

Methods: The biogenic AuNPs was synthesized using an aqueous extract of Marsilea quadrifolia. The synthesized biogenic AuNPs were characterized by ultraviolet (UV) visible spectroscopy, transmission electron microscopy (TEM), energy dispersive X-ray analysis (EDX) and X-ray diffraction (XRD). The biogenic AuNPs was assessed for its stability over a period of time and antioxidant activity. The cytotoxicity of biogenic AuNPs against PA-1 and A549 cell lines was studied using 3-(4,5-dimethylthiazol-2-yl)-2,5-diphenyltetrazolium bromide (MTT) assay.

Results: The synthesized biogenic AuNPs showed peculiar ruby red color and a surface plasmon resonance (SPR) peak at 544 nm in the UV-Vis spectrum. The characterization of biogenic AuNPs by TEM, EDX and XRD revealed well dispersed spherical particles ranging from 10-40 nm and the presence of elemental gold and its crystalline nature, respectively. The AuNPs showed good stability and the scavenging activity at $50 \mu \mathrm{g} / \mathrm{ml}$. The in vitro cytotoxicity of biogenic AuNPs against PA-1 and A549 cell lines recorded half maximal inhibitory concentration (IC 50 ) of $45.88 \mu \mathrm{g} / \mathrm{ml}$ and $52.015 \mu \mathrm{g} / \mathrm{ml}$, respectively.

Conclusion: The biogenic AuNPs demonstrated superior antioxidant and antiproliferative activities against cancer cell lines.

Keywords: Biogenic, Gold nanoparticles, Marsilea quadrifolia, Antioxidant, Cytotoxicity

(C) 2018 The Authors. Published by Innovare Academic Sciences Pvt Ltd. This is an open access article under the CC BY license (http://creativecommons.org/licenses/by/4.0/) DOI: http://dx.doi.org/10.22159/ijap.2018v10i5.27999

\section{INTRODUCTION}

Cancer is a most highly enigmatic and complex disease responsible for the major decline in mortality. It is a multistep carcinogenesis process encompassing numerous cellular physiological systems such as cell signaling and apoptosis [1]. The early recognition and treatment of cancer remain a technological obstruction. The current diagnostic methods are insufficient to make predictions for successful treatment. Thus, there is an immediate need for a unique and comprehensive technology against cancer for its early diagnosis, personalized therapy, and medicine [2].

Nanotechnology has revolutionized the field of medicine and accelerated the growth of Nanomedicine, a new field of interest among the researchers, having a tremendous potential of enhanced bioavailability with a simultaneous reduction in toxicity and side effects of the drug [3]. Among the nanoparticles, the bio-reduced gold and silver nanoparticles have gained utmost importance in biomedical application [4]. Besides, the metallic nanoparticles have a tunable surface plasmon resonance (SPR) which enables biolabelling [5]. It is flexible for surface functionalization with various biomolecules (protein, DNA, algae, enzymes, and plantderived bioactive compounds) [6].

The biosynthesis of metallic nanoparticles is an interesting technology as it aims to minimize the generation of a hazardous substance to health and environment. A broad classification of living organisms (cyanobacteria, bacteria, fungi, actinomycetes, biomolecules and various plant materials) are already well-known to synthesize nanostructured composites [7]. Rapid and biosynthesis methods using biological sources have shown a greater potential for nanoparticles synthesis, however, understanding the involvement of biomolecules is lacking [8]. Nanostructured materials showed many aspects of interesting characteristics, i.e., optical, catalytic, that greatly depends on the size and shape of nanoparticles.
Marsilea quadrifolia L. (Family: Marsileaceae), an aquatic fern is found abundantly in eastern and southern regions of India [9]. The aerial part of M. quadrifolia extract using chloroform and ethyl acetate has shown proven antibacterial, cytotoxic, and antioxidant effect [10] Moreover, methanolic extract of $M$. quadrifolia fern has been reported to the higher efficiency of glucose utilization and cellular viability in 3T3-L1 adipocytes with lower toxicity [11]. Thus, in the current investigation, the gold nanoparticles (AuNPs) were synthesized by employing the aqueous leaf extract of $M$. quadrifolia as a reducing agent. The biogenic AuNPs were characterized and evaluated for its antioxidant property and cytotoxic effect on two different cancer cell lines such as human ovarian teratocarcinoma (PA-1) and lung adenocarcinoma (A549) cells under in vitro condition.

\section{MATERIALS AND METHODS}

\section{Chemicals}

Tetra chloroauric acid or gold chloride $\left(\mathrm{HAuCl}_{4}\right)$ was purchased from Hi-media Lab Pvt. Ltd. (Mumbai, India). Cell culture Dulbecco's modified eagle medium (DMEM), fetal bovine serum (FBS) and 0.25 $\%$ trypsin-EDTA were purchased from Gibco (Grand Island, NY, USA). Streptomycin, penicillin, dimethyl sulfoxide (DMSO), (3-(4, 5dimethylthiazol-2-yl)-2, 5-diphenyltetrazolium bromide) (MTT) and phosphate buffer were purchased from the Sigma-Aldrich (St Louis, MO, USA).

\section{Plant samples and preparation of plant extracts}

The leaves of five different plants namely Cassia javanica (ABP01), Melia azedarach (ABP02), Marsilea quadrifolia (ABP03), Stachytarpheta jamaicensis (ABP04), Spathodea campanulata (ABP05) were collected from different parts of Chennai. The leaves were washed to remove impurities, air-dried in the shade and then grounded. The dried leaf powder samples (4.0 g) were taken separately and mixed with $100 \mathrm{ml}$ of sterile distilled water. The 
mixtures were boiled at $55{ }^{\circ} \mathrm{C}$ for $15 \mathrm{~min}$ and then cooled to room temperature and filtered through Whatman No.1 filter paper. The aqueous extract was collected, refrigerated and used for further experiments [12].

\section{Biogenic synthesis of gold nanoparticles}

The biogenic synthesis of AuNPs was carried out according to Balashanmugam et al. [13] method with modifications. Briefly, 1.0 $\mathrm{ml}$ of the aqueous leaf extract was added to $9.0 \mathrm{ml}$ of $1.0 \mathrm{mmol}$ of $\mathrm{HAuCl}_{4}$ separately and incubated in the dark at room temperature for $24 \mathrm{~h}$. The visual observation of change in color from golden yellow to ruby red color indicates the formation of AuNPs.

\section{Characterization of biogenic AuNPs}

\section{UV-Visible Spectroscopy and stability}

The formation of phytosynthesized AuNPs was confirmed by measuring the absorption spectra between $300-700 \mathrm{~nm}$ in PC based Systronics double beam spectrophotometer 2202. The stability of the biogenic AuNPs was recorded at different time intervals such as $6 \mathrm{~h}$, $12 \mathrm{~h}, 18 \mathrm{~h}, 24 \mathrm{~h}, 10^{\text {th }}$ day, $20^{\text {th }}$ day, $30^{\text {th }}$ day, $45^{\text {th }}$ day and $60^{\text {th }}$ day. The absorbance was measured using the above-mentioned instrument.

Transmission electron microscopy (TEM) and energy dispersive $\mathrm{X}$-ray analysis (EDX)

The biogenic AuNPs were characterized for its morphology and size by performing TEM (TECNAI 30 G2S-TWIN, FEI Company). A drop of biogenic synthesized AuNPs was placed on the carbon-coated copper grid; the extra solution was removed using a blotting paper and then the film was dried and analyzed. The EDX analysis was conducted in the above instrument to confirm the presence of the different elemental composition of the sample [14].

\section{$\mathrm{X}$-ray diffraction (XRD)}

The lyophilized biogenic AuNPs were studied by XRD measurements with the help of powder X-ray diffractometry (SEIFERT JSO DEBYEFLEX 2002). The analysis was carried out with $\mathrm{Cu} \mathrm{K \alpha}$ radiation at a wavelength of $1.5406 \AA$ with the operating condition at $40 \mathrm{kV}, 30 \mathrm{~mA}$. The XRD pattern was scanned in the $2 \theta$ from $30^{\circ}$ to $70^{\circ}$ with a step size of $0.04^{\circ}$ per second [13].

\section{Determination of free radical scavenging activity}

The radical scavenging activity of biogenic AuNPs was determined using 1, 1-diphenyl-2-picrylhydrazyl (DPPH) assay according to Rajamanikandan et al. [15]. Different concentrations $(10,25,50$, 100,250 and $500 \mu \mathrm{g} / \mathrm{ml}$ ) of biogenic AuNPs was mixed with $2 \mathrm{ml}$ of $4 \mathrm{mmol}$ methanolic DPPH and incubated in the dark at room temperature for $15 \mathrm{~min}$. After incubation, the absorbance of the samples was measured by using UV-vis spectrophotometer at 517 $\mathrm{nm}$ against methanol as blank. Ascorbic acid was used as a standard, and methanolic DPPH reagent without sample was used as a control. The ability to scavenge DPPH radical was calculated by the following equation:

$$
\begin{gathered}
\text { Inhibition }(\%)=((\text { Absorbance } \text { control }- \text { Absorbance test }) / \text { Absorbance } \\
\text { control }) \times 100 \text {. }
\end{gathered}
$$

\section{Collection of the cell line and cell maintenance culture}

The PA-1 ovarian teratocarcinoma cell line and A549 lung adenocarcinoma cell line was obtained from the national center for cell sciences (NCCS), Pune, India. Cells were maintained in the logarithmic growth phase in DMEM medium containing L-glutamine $(2 \mathrm{mmol})$, sodium bicarbonate $(\mathrm{g} / \mathrm{l})$, glucose $(4.5 \mathrm{~g} / \mathrm{l})$, HEPES $(10 \mathrm{mmol})$ and sodium pyruvate $(1.0 \mathrm{mmol})$. It was supplemented with $10 \%(\mathrm{v} / \mathrm{v})$ heatinactivated fetal bovine serum, $100 \mu \mathrm{g} / \mathrm{ml}$ penicillin, $100 \mu \mathrm{g} / \mathrm{ml}$ streptomycin in an air humidified incubator with $5 \% \mathrm{CO}_{2}$ at $37^{\circ} \mathrm{C}$.

\section{Cytotoxic effect of biogenic AuNPs on cancer cell lines-MTT assay}

The cytotoxicity test of biogenic AuNPs synthesized from $M$. quadrifolia leaf aqueous extract was performed against two cancer cell lines such as PA-1 and A549 using 3-(4,5-dimethylthiazol-2-yl-)2,5-diphenyltetrazolium bromide (MTT) assay [16]. Briefly, the cell suspensions were separately seeded on 96-well microplates $\left(1 \times 10^{6}\right.$ cells $/ \mathrm{ml}$ ) and incubated for $24 \mathrm{~h}$ at $37{ }^{\circ} \mathrm{C}$. After $90 \%$ of cell confluence, PA-1 and A549 cells were treated with different concentrations $(10,20,40,60,80$ and $100 \mu \mathrm{g} / \mathrm{ml})$ of biogenic AuNPs incubated for $24 \mathrm{~h}$ at $37{ }^{\circ} \mathrm{C}$. The untreated cells were marked as a control. After $24 \mathrm{~h}$ of treatment, the medium was removed and the cells were washed with phosphate-buffered saline (PBS, $\mathrm{pH}$ 7.4) and incubated with $20 \mu \mathrm{L}$ of MTT ( $5 \mathrm{mg} / \mathrm{ml}$ in PBS) for $4 \mathrm{~h}$ at $37^{\circ} \mathrm{C}$. Then $100 \mu \mathrm{L}$ of DMSO was added to each well to dissolve the formazan crystals. Finally, the absorbance was read at $570 \mathrm{~nm}$ using ELISA plate reader. The cell viability percentage was expressed as follows:

Cell viability $(\%)=($ Absorbance of treated cells $/$ Absorbance of control cells) $\times 100$.

\section{RESULTS AND DISCUSSION}

\section{Biogenic synthesis of AuNPs}

The aqueous leaf extracts of five different plants namely Cassia javanica, Marsilea quadrifolia, azedarach, Spathodea campanulata Stachytarpheta jamaicensis were used for the synthesis of AuNPs. Among the tested plants, the AuNPs synthesized using M. quadrifolia aqueous leaf extract showed ruby red color with higher stability than the other tested samples (fig. 1). Therefore, M. quadrifolia leaf extract was chosen for further studies. A similar observation of appearance of ruby red color that indicates the formation of AuNPs was reported using Cinnamomum zeylanicum [17], Sorbus aucuparia [18], Rosa rugosa [19], and Mangifera indica [20].
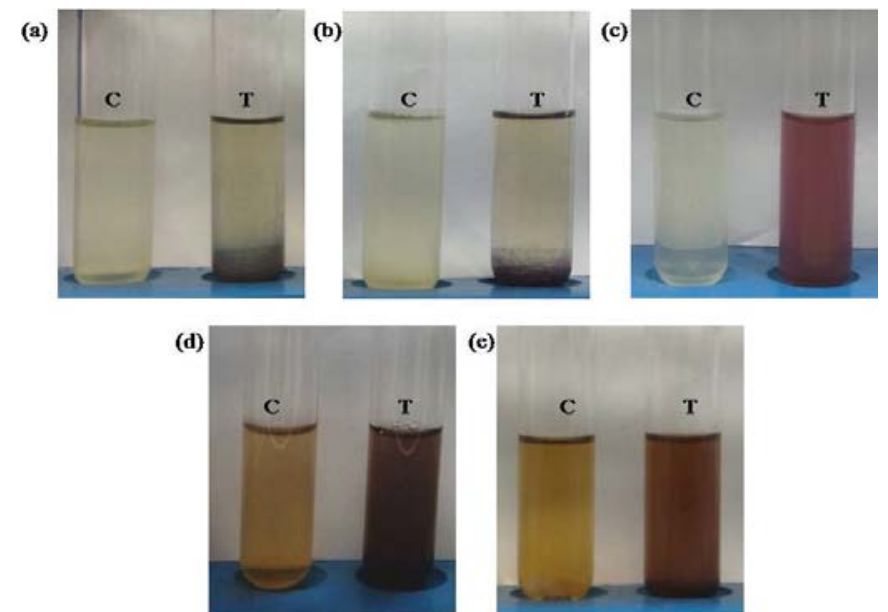

Fig. 1: Biogenic synthesis of gold nanoparticles (AuNPs) using different plants. (a) Cassia javanica, (b) Melia azedarach, (c) Marsilea quadrifolia, (d) Stachytarpheta jamaicensis and (e) Spathodea campanulata 


\section{Characterization of biogenic AuNPs}

\section{UV-visible spectroscopy and stability}

The AuNPs synthesized using M. quadrifolia revealed an SPR peak at $544.8 \mathrm{~nm}$ in the UV-Vis spectra, confirming the formation of AuNPs (fig. 2a). Similar behavior of AuNPs has been reported by Mukundan et al. [21]. The stability of the biogenic AuNPs was monitored under UV-visible spectroscopy at different time durations (6 h-2 mo). It was observed that the synthesis had started within $6 \mathrm{~h}$ with a peak at $538 \mathrm{~nm}$ and remained up to $12 \mathrm{~h}$. Thereafter, there was a shift in the peak to $541 \mathrm{~nm}$ at $18 \mathrm{~h}$. The reaction ended at $24 \mathrm{~h}$ with an absorption peak at $544 \mathrm{~nm}$, and the two-month-old sample also exhibited a peak at $544 \mathrm{~nm}$, thus indicating the higher stability of biogenic AuNPs of M. quadrifolia (fig. 2b). The stability of AuNPs depends on the choice of plant and the presences of phytochemicals [22].

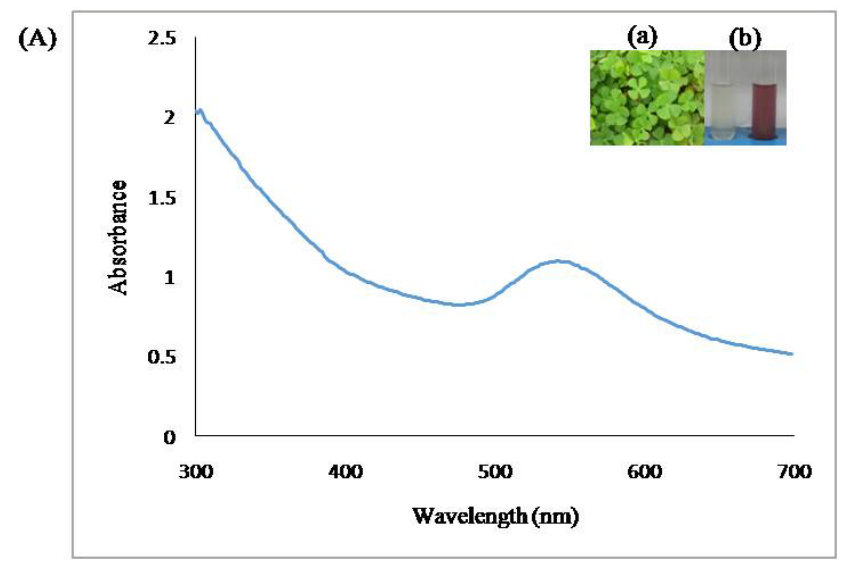

(B)

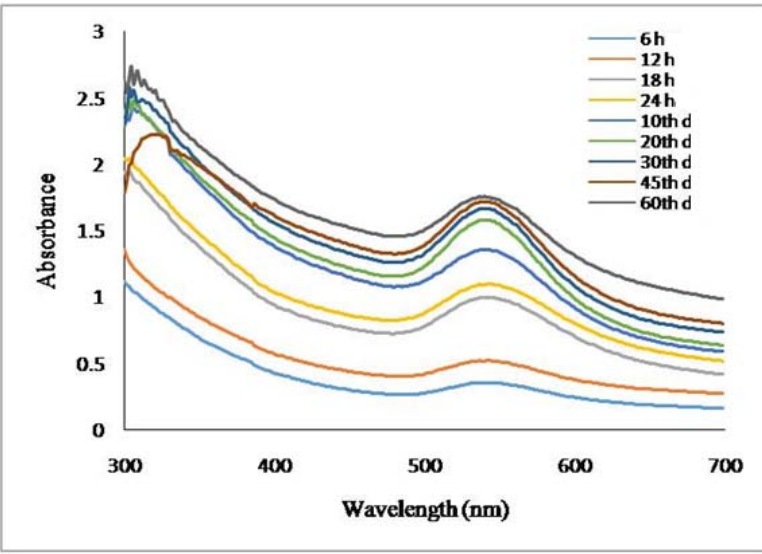

Fig. 2: (A) UV-Vis spectrum of biogenic AuNPs synthesized from Marsellia quardifolia aqueous leaves extract. Inset (a) habitat, (b) biogenic AuNPs synthesized, (B) Stability of AuNPs at different time durations. Abbreviations: $h$ ( $n=9$ )

(a)
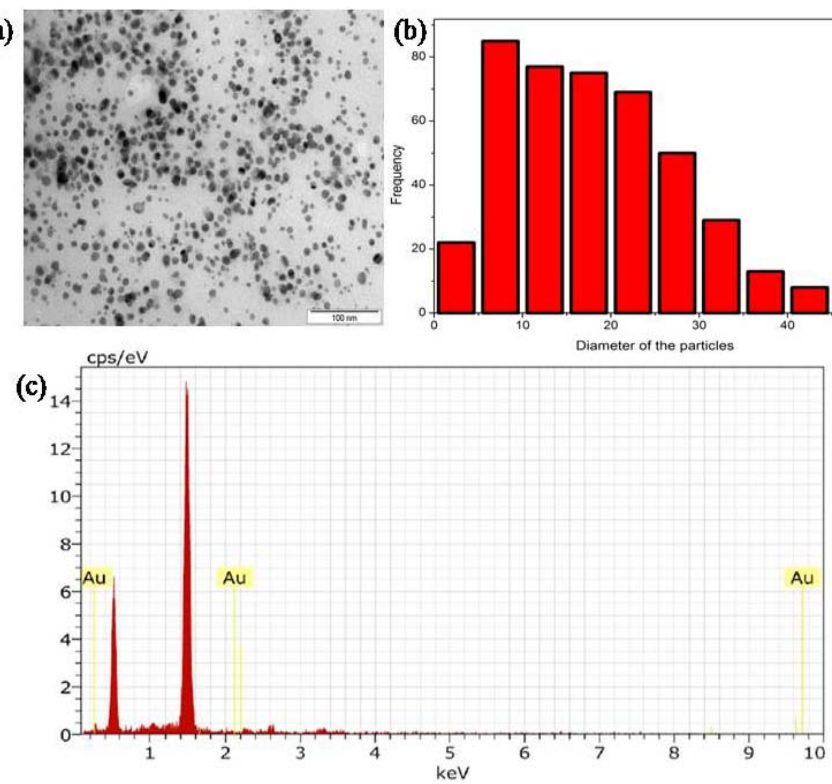

Fig. 3: Characterization of biogenic AuNPs. (a) TEM image of spherical shaped AuNPs, (b) Size distribution of particles, (c) EDX spectrum 
Transmission electron microscopy and energy dispersive X-ray analysis

The TEM analysis revealed that the biogenic AuNPs were mostly spherical in shape and well dispersed in nature with a particle size range of 10 to $40 \mathrm{~nm}$ (fig. 3a and 3b). Similarly, Bhau et al. [23] reported the synthesis of spherical shape AuNPs to range from $50 \mathrm{~nm}$ to $80 \mathrm{~nm}$ using $N$. Khasiana leaf extracts. The biogenic AuNPs EDX spectrum showed a single and strong signal for gold (Au), indicating that the NPs that were neutral (fig. 3c). Similar observations were made by Elavazhagan [24] with Mesembryanthemum edule gold nanoparticles.

\section{X-ray diffraction (XRD) studies}

The XRD pattern revealed five distinct peaks at $38.21^{\circ}, 44.39^{\circ}$, $64.62^{\circ}, 77.59^{\circ}$ and $82.09^{\circ}$ corresponding to (111), (200), (220), (311) and (222) planes respectively (fig. 4), representing the facecentered cubic (fcc) structure of the AuNPs. The data obtained was matched with the database of joint committee on powder diffraction standards (JCPDS) file No. 65-2870, indicating that the biogenic AuNPs are crystalline in nature. Much similar to our present report, Fazaludeen et al. [25] has reported the XRD patterns for gold nanoparticles synthesized using Justicia gendarussa leaf extract.

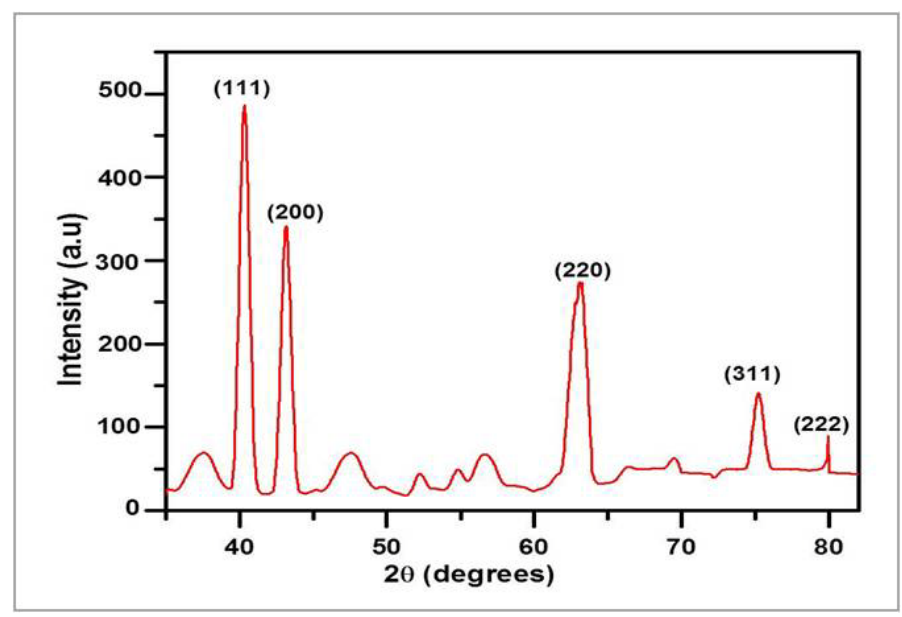

Fig. 4: XRD pattern of biogenic AuNPs

\section{Determination of free radical scavenging activity}

The free radical scavenging activity of the biogenic AuNPs was assessed by DPPH assay by using ascorbic acid as a positive control. The biogenic AuNPs were able to reduce the stable radical DPPH to the yellow-colored diphenyl-picrylhydrazine. The AuNPs showed a dose-dependent activity, and the inhibitory concentration $\left(\mathrm{IC}_{50}\right)$ was found at a concentration of $50 \mu \mathrm{g} / \mathrm{ml}$ whereas the standard ascorbic acid inhibitory concentration was recorded at $10 \mu \mathrm{g} / \mathrm{ml}$ (fig. 5) Accordance of observations have been reported by AuNPs synthesized using Lemna minor, Gymnema sylvestre, Sumac with enhanced antioxidant activity [26-28].

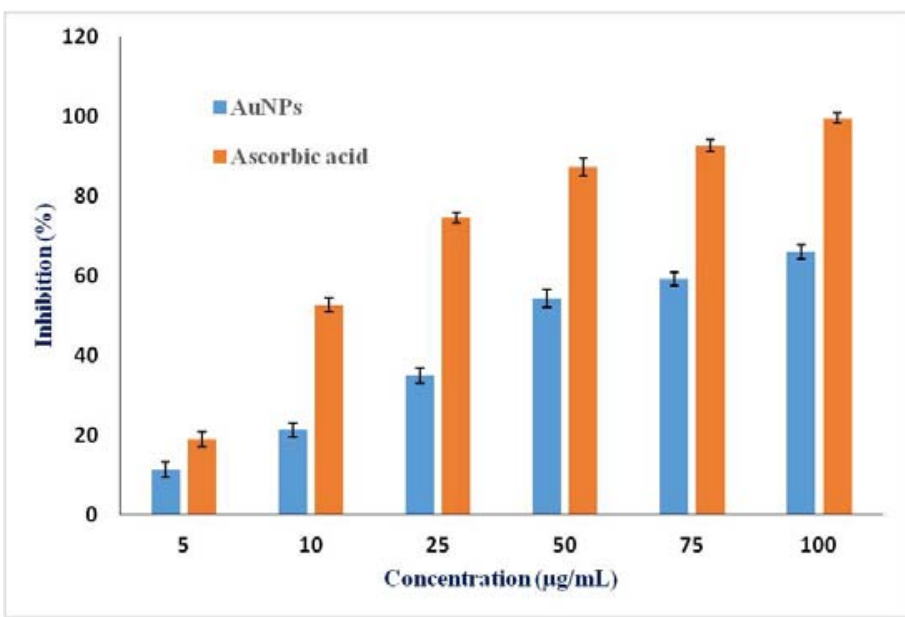

Fig. 5: Antioxidant activity of biogenic AuNPs, values are given as mean \pm SD for each concentration ( $n=6)$

\section{Effect of AuNPs induced cytotoxicity on cancer cell lines}

The MTT assay was performed to examine the in vitro cytotoxic effect of biogenic AuNPs against PA-1 and A549. The viability of the PA-1 and A549 cell lines was observed after $24 \mathrm{~h}$ of treatment with biogenic AuNPs. A significant decrease in the cell viability was observed with increasing concentrations of the biogenic AuNPs when compared to control. The $\mathrm{IC}_{50}$ value for PA- 1 and A549 cells was recorded at 45.88 $\mu \mathrm{g} / \mathrm{ml}$ and $52.01 \mu \mathrm{g} / \mathrm{ml}$, respectively, at $24 \mathrm{~h}$ (fig. 6a). The AuNPs treated cancer cells appeared as irregular and annular-shaped conglomerates, whereas the control cells were normal in shape (fig. 6b). Rajeshkumar [29] reported the inhibitory effect of AuNPs at 100 $\mu \mathrm{g}$ concentration of nanoparticles against A549 cells. The cytotoxicity of AuNPs is believed to be the active physicochemical interaction of gold atoms with the functional groups of the intracellular proteins, as well as with the nitrogen bases and phosphate groups in DNA [2]. The reduced cell viability of PA-1 and A549 cells observed in this study is suggestive of anticancer effects of AuNPs and further studies are required to be done to understand the process of cell death by apoptosis or necrosis pathway. 
(A)

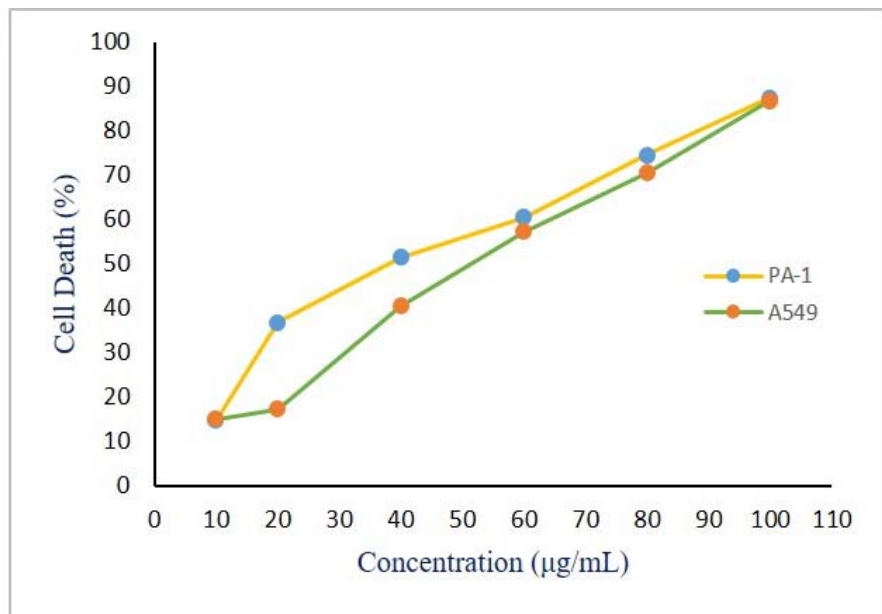

(B)
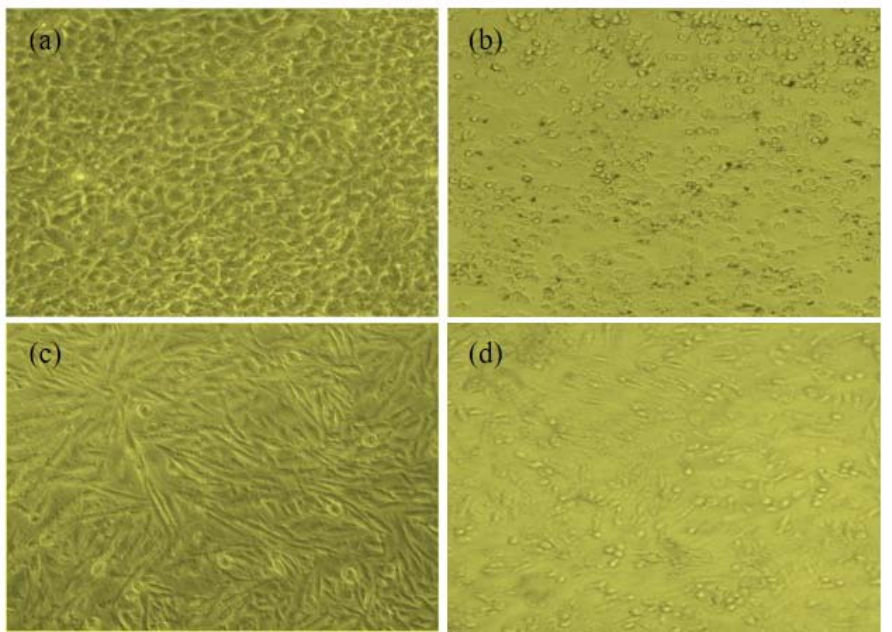

Fig. 6: (A) Cytotoxicity of different concentration of biogenic AuNPs on PA1 and A549. (B) Cytotoxic effect of AuNPs on PA1 and A549 cell line. (a) and (c) Control, (b) and (d) IC50 treated cells, respectively. Values are given as mean \pm SD for each concentration (n=6)

\section{CONCLUSION}

The process for the synthesis of nanoparticles in large scale using the readily available plant extract may have commercial viability and to develop an interface between biology and material science. The stable bioactive AuNPs were synthesized using M. quadrifolia leaf extract. The phytochemicals present in the extract of $M$. quadrifolia has reduced the gold ions into metallic nanoparticles. The biogenic AuNPs exhibited a substantial in vitro antioxidant activity and cytotoxicity effect against both PA-1 and A549 cancer cells. Such biogenic AuNPs are expected to serve as potent anticancer agents and thus can be used in biomedical applications.

\section{ACKNOWLEDGMENT}

We wish to thank, The Director, CSIR-CLRI, Chennai for providing laboratory and instrumentation facility. We also thank The Director, Avanz Bio Pvt. Ltd., for providing the cell culture laboratory facilities.

\section{AUTHORS CONTRIBUTIONS}

All the author have contributed equally

\section{CONFLICTS OF INTERESTS}

The authors report no conflicts of interest in performing this work

\section{REFERENCES}

1. Reichert JM, Wenger JB. Development trends for new cancer therapeutics and vaccines. Drug Discovery Today 2008;13:30-7.

2. Misra R, Acharya S, Sahoo SK. Cancer nanotechnology: application of nanotechnology in cancer therapy. Drug Discovery Today 2010;15:842-50.
3. Ventola CL. The nanomedicine revolution: part 2: current and future clinical applications. Pharm Ther 2012;37:582-91.

4. Mody V, Siwale R, Singh A, Mody H. Introduction to metallic nanoparticles. J Pharm Bioall Sci 2010;2:282-9.

5. Lu C, Mohwald H, Fery A. Plasmon resonance tunable by deaggregation of gold nanoparticles in multilayers. J Phys Chem C 2007;111:10082-7.

6. Nel A, Madler L, Velegol D, Xia T, Hoek E, Somasundaran P, et al. Understanding biophysicochemical interactions at the nano-bio interface. Nat Mater 2009;8:543-57.

7. Gardea Torresdey J, Parsons J, Gomez E, Peralta Videa J, Troiani $\mathrm{H}$, Santiago P, et al. Formation and growth of Au nanoparticles inside live Alfalfa plants. Nano Lett 2002;2:397-401.

8. Inbakandan D, Venkatesan R, Ajmal Khan S. Biosynthesis of gold nanoparticles utilizing marine sponge Acanthella elongata (Dendy, 1905). Colloids Surf B 2010;81:634-9.

9. Strat D. Conservation status and conservation strategies of threatened aquatic fern Marsilea quadrifolia L. in Europe. Forum Geografic 2014;XIII:193-202.

10. Ripa F, Nahar L, Haque M, Islam M. Antibacterial, the cytotoxic and antioxidant activity of crude extract of Marsilea quadrifolia. Eur J Sci Res 2009;33:123-9.

11. Chowdhury A, Kunjiappan S, Bhattacharjee C, Somasundaram B, Panneerselvam T. Biogenic synthesis of Marsilea quadrifolia gold nanoparticles: a study of improved glucose utilization efficiency on 3T3-L1 adipocytes. In Vitro Cell Dev Biol Anim 2017;53:483-93.

12. Balashanmugam $\mathrm{P}$, Kalaichelvan PT. Biosynthesis characterization of silver nanoparticles using Cassia roxburghii DC. aqueous extract, and coated on cotton cloth for effective antibacterial activity. Int J Nanomed 2015;10:87-97. 
13. Balashanmugam P, Durai P, Balakumaran M, Kalaichelvan PT. Photosynthesized gold nanoparticles from $C$. roxburghii DC. leaf and their toxic effects on normal and cancer cell lines. J Photochem Photobiol 2016;165:163-73.

14. Parida U, Bindhani B, Nayak P. Green synthesis and characterization of gold nanoparticles using onion (Allium cepa) extract. World J Nano Sci Eng 2011;1:93-8.

15. Rajamanikandan S, Sindhu T, Durgapriya D, Sophia D Ragavendran P, Gopalakrishnan VK. Radical scavenging and antioxidant activity of ethanolic extract of Mollugo nudicaulis by in vitro assays. Ind J Pharm Edu Res 2011;45:310-6.

16. Meerloo JV, Kaspers GJL, Cloos J. Cell sensitivity assays: the MTT assay. Methods Mol Bio 2011;731:237-45

17. Smitha S, Philip D, Gopchandran K. Green synthesis of gold nanoparticles using Cinnamomum zeylanicum leaf broth. Spectrochim Acta Part A 2009;74:735-9.

18. Dubey S, Lahtinen M, Sarkka H, Sillanpaa M. Bioprospective of Sorbus aucuparia leaf extract in development of silver and gold nanocolloids. Colloids Surf B 2010;80:26-33.

19. Dubeya SP, Lahtinenb M, Sillanpaaa M. Synthesis and characterizations of gold nanoparticles by Justicia gendarussa Burm F leaf extract. Colloids Surf B 2010;364:34-41.

20. Philip D. Mangifera Indica leaf-assisted biosynthesis of welldispersed silver nanoparticles. Spectrochim Acta Part A 2011;78:327-31.

21. Mukundan D, Mohankumar R, Vasanthakumari R. Green synthesis of silver nanoparticles using leaves extract of Bauhinia tomentosa Linn and its in vitro anticancer potential. Mater Today 2015;2:4309-16.
22. Krishnaraj C, Muthukumaran P, Ramachandran R, Balakumaran MD, Kalaichelvan PT. Acalypha indica linn: biogenic synthesis of silver and gold nanoparticles and their cytotoxic effects against MDA-MB-231, human breast cancer cells. Biotechnol Rep 2014;4:42-9.

23. Bhau BS, Ghosh S, Puri S, Borah B, Sarmah DK, Khan R. Green synthesis of gold nanoparticles from the leaf extract of Nepenthes khasiana and antimicrobial assay. Adv Mater Lett 2015;6:55-8.

24. Elavazhagan T, Arunachalam KD. Memecylon edule leaf extract mediated green synthesis of silver and gold nanoparticles. Int J Nanomed 2011;6:1265-78.

25. Fazaludeen MF, Manickam C, Ashankyty IMA, Ahmed MQ, Beg QZ. Synthesis and characterizations of gold nanoparticles by Justicia gendarussa burm F leaf extract. J Microbiol Biotech Res 2012;2:23-34.

26. Saritha K, Saraswathi U. Antioxidant activity of gold nanoparticles synthesized using Lemna minor. World J Pharm Sci 2014;2:1545-51.

27. Nakkala J, Mata R, Bhagat E, Sadras S. Green synthesis of silver and gold nanoparticles from Gymnema sylvestre leaf extract: study of antioxidant and anticancer activities. J Nanopart Res 2015;17:151.

28. Shabestarian H, Homayouni Tabrizi M, Soltani M, Namvar F, Azizi S, Mohamad R, et al. Green synthesis of gold nanoparticles using Sumac aqueous extract and their antioxidant activity. Mat Res 2017;20:264-70.

29. Rajeshkumar S. Anticancer activity of eco-friendly gold nanoparticles against lung and liver cancer cells. J Genet Eng Biotechnol 2016;14:195-202. 